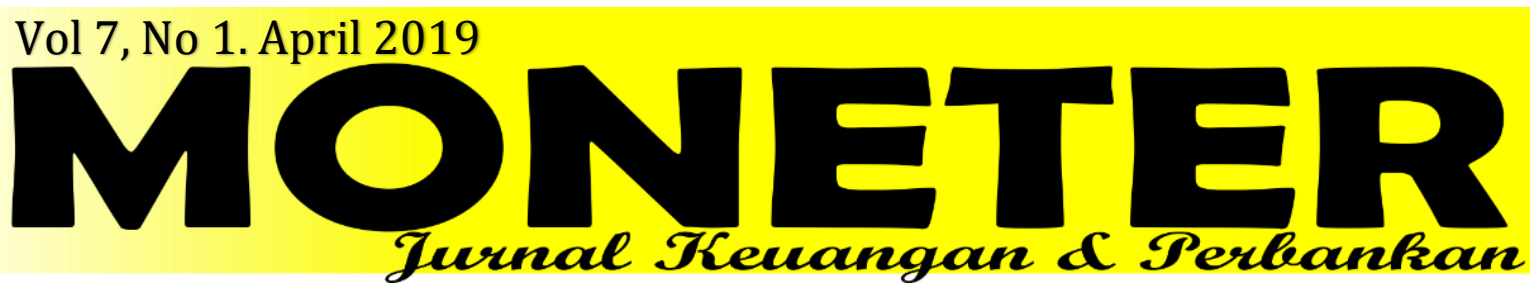

\title{
PERLAKUAN TERHADAP WARKAT YANG DITOLAK PADA PROSES KLIRING PADA PT. BANK X (PERSERO) Tbk. AREA BOGOR
}

\author{
Supramono dan Agita Karalina \\ Program Studi Keuangan dan Perbankan Fakultas Ekonomi dan Bisnis \\ Universitas Ibn Khaldun \\ supramono@uika-bogor.ac.id
}

\begin{abstract}
Abstrak
Pembayaran pada awalnya terjadi dengan menggunakan sistem barter, seiring dengan perkembangan perekonomian yang semakin meningkat uang kartal digunakan sebagai alat pembayaran dan uang giral sebagi alat-alat lalu lintas pembayaran. Salah satu sistem yang dapat digunakan dalam penyelesaian pembayaran menggunakan uang giral adalah kliring. PT.Bank X (Persero) Tbk Area Bogor adalah salah satu Bank yang menyediakan jasa kliring dan merupakan peserta kliring wilayah Bogor. Tujuan penelitian Tugas Akhir ini adalah untuk mengetahui proses kliring, penyebab terjadinya tolakan, perlakuan warkat yang ditolak dan peristiwa menang atau kalah kliring pada Bank $\mathrm{X}$ Area Bogor. Sedangkan perlakuan terhadap warkat yang ditolak yaitu warkat difotocopy untuk lampiran Surat keterangan penolakan (SKP), warkat asli dikembalikan kecuali warkat blokir karena surat kehilangan dari kepolisian, warkat diduga palsu/ dimanipulasi.
\end{abstract}

Kata Kunci : kliring, warkat, proses kliring

\section{Pendahuluan}

\section{Latar Belakang}

Sejalan

dengan perkembangan perekonomian yang semakin meningkat selain uang kartal yang digunakan sebagai alat pembayaran terdapat juga uang giral sebagi alat-alat lalu lintas pembayaran. Uang giral terdiri dari cek, bilyet giro, Surat Bukti Penerimaan Transfer (SBPT), Wesel Bank Untuk Transfer (WBUT), nota debit, dan nota kredit. Penggunaan alat pembayaran giral ini sesuai dengan kebutuhan masyarakat akan kecepatan, kehandalan dan keamanan dalam bertransaksi. Para pelaku usaha menginginkan agar kegiatan usahanya dapat terus berputar dan kecepatan pembayaran atau bertransaksi dapat menunjang kegiatan usaha.

Sesuai dengan undang-undang nomor 23 tahun 1999 tentang Bank Indonesia sebagaimana telah diubah terakhir dengan
Undang-Undang Nomor 6 Tahun 2009, Bank Indonesia mempunyai tugas untuk megatur dan menjaga kelacaran sistem pembayaran dan dalam rangka mendukung terwujudnya sistem pembayaran yang efisien, cepat, aman dan andal dimaksudkan untuk mendukung stabilitas sistem keuangan.

Sehubungan dengan tugas Bank Indonesia dalam bidang sistem pembayaran, Bank Indonesia telah menyediakan fasilitas kliring yang merupakan pertukaran data keuangan elektronik dan/atau warkat anatara peserta kliring baik atas nama peserta maupun atas nama nasabah yang perhitungannya diselesaikan.ada waktu tertentu. Transaksi yang di proses melalui fasilitas kliring meliputi transfer debet dan transfer kredit yang disertai dengan pertukaran fisik warkat, baik warkat debet (cek, bilyet giro, nota debet, dan lain- 
lain) maupun warkat kredit (nota kredit) yang kemudian akan dikirim oleh bank melalui data keuangan elektronik yang disediakan dalam SKNBI (Sistem Kliring Nasional Bank Indonesia).

\section{Rumusan Masalah}

Pada penelitian ini, dirumuskan masalah yaitu:

1. Bagaimana proses pelaksanaan kliring ?

2. Apa saja yang bisa menyebabkan terjadinya tolakan kliring?

3. Bagaimana perlakuan terhadap warkat yang ditolak pada Bank X?

\section{Tujuan Penelitian}

1. Mengetahui proses pelaksanaan kliring.

2. Untuk mengetahui penyebab terjadinya tolakan kiring pada bank.

3. Untuk mengetahui perlakuan warkat yang di tolak.

\section{Kajian Teori}

\section{Bank}

Bank dikenal sebagai lembaga keuangan yang kegiatan utamanya menerima simpanan giro, tabungan dan deposito. Kemudian bank juga dikenal sebagai tempat untuk meminjam uang (kredit) bagi masyarakat yang membutuhkannya. Disamping itu, bank juga dikenal sebagai tempat untuk menukar uang, memindahkan uang atau menerima segala macam bentuk pembayaran dan setoran seperti pembayaran listrik, telepon, air, pajak, dan pembayaran lainnya. Berikut dapat dikemukakan beberapa pendapat tentang pengertian bank, yaitu :

Menurut UU RI Nomor 10 Tahun 1998 tanggal 10 November 1998 tentang perbankan, yaitu " badan usaha yang menghimpun dana dari masyarakat dalam bentuk simpanan dan menyalurkannya kepada masyarakat dalam bentuk kredit dan atau bentuk-bentuk lainnya dalam rangka meningkatkan taraf hidup rakyat banyak." (Kasmir,2014: 24)

Menurut Buku dasar-dasar perbankan secara sederhana bank diartikan sebagai

\section{Manfaat Penelitian}

1. Bagi Perusahaan atau Bank

Dapat dijadikan sebagai bahan rujukan ataupun masukan bagi perusahaan untuk melihat perkembangan perusahaan dalam hal proses penolakan kliring.

2. Bagi Penulis

Untuk menambah pengetahuan penulis dengan pengalaman yang sebenarnya dalam dunia kerja. Mendorong semangat penulis untuk berjiwa kewiraswastaan. Menerapkan kemampuan yang dimiliki penulis dalam dunia kerja.

3. Bagi Pihak-Pihak lain diharapkan kasil karya ilmiah ini dapat menambah referensi, informasi dan wawasan untuk penelitian lebih lanjut atas sebagai bahan kepustakaan serta sumber pengetahuan.

lembaga keuangan yang kegiatan usahanya adalah menghimpun dana dari masyarakat dan menyalurkan kembali dana tersebut ke masyarakat serta memberikan jasa-jasa bank lainnya (Kasmir, 2014:2)

Dari pengertian di atas dapat disimpulkan bahwa bank merupakan perusahaan yang bergerak dalam bidang keuangan, artinya aktivitas perbankan selalu berkaitan dalam bidang keuangan.

\section{Kliring}

Kliring dibentuk oleh Bank Indonesia (BI) pada tanggal 3 Maret 1967. Kata clearing berasal dari kata "clear" ynag berarti jelas atau terang. Penggunaan kata clear menjadi clearing berasal dari kata kerja toclear yang artinya membersihkan dan penyelesaian. Istilah clearing kemudian di bahasa indonesiakan menjadi kliring.

Kliring merupakan jasa penyelesaian utang piutang antar bank dengan cara saling menyerahkan warkat-warkat yang akan dikliringkan di lembaga kliring. Penyelesaiaan utang piutang dimaksudkan adalah penagihan 
cek atau bilyet giro melalui bank.(Kasmir;2014;172)

Kemudian yang dimaksud dengan lembaga kliring adalah lembaga yang di bentuk Bank Indonesia setiap hari kerja. Bank yang ikut kliring disebut peserta kliring dan merupakan bank yang sudah memperoleh ijin dari Bank Indonesia. Kliring adalah pertukaran warkat atau Data Keuangan Elektronik (DKE) antar peserta kliring baik atas nama bank peserta maupun atas nama nasabah peserta yang perhitungannya diselesaikan pada waktu tertentu.

Tujuan utama dilaksanakan kliring oleh bank indonesia antara lain:

1. Untuk memajukan dan memperlancar lalu lintas pembayaran giral antar bank diselurh indonesia.

\section{Metode Penelitian}

Kegiatan Praktek Kerja Lapangan dilaksanakan dengan dua metode yaitu metode secara langsung dan secara tidak langsung. Metode secara langsung yang telah dilaksanakan selama Praktek Kerja Lapangan meliputi kegiatan yang menyangkut aspek

\section{Pembahasan}

Selama melaksanakan praktek kerja lapangan (PKL) terdapat temuan antara lain :

1. Nasabah mengkliringkan warkatnya namun belum waktunya pada waktu efektif tetapi sudah dijalankan yang seharusnya warkat ditolak tetapi dijalankan maka hal tersebut bisa mengakibatkan kerugian di salah satu pihak sebagai nasabah

2. pada saat penerimaan warkat masuk terjadi kesalahan terdapat warkat milik bank sendiri.

3. Salah posting warkat, tertukar yang seharusnya BG jadi Cek.

4. Pada saat teller memposting warkat bank lain terjadi kesalahan input nominal sebesar Rp.500, karna kelalaian teller dan
2. Agar perhitungan penyelesaian utang piutang dapat dilaksanakan lebih mudah, aman, dan efisien.

3. Salah satu layanan bank kepada nasabah masing - masingnya, terutama dalam hal keamanan dan biaya yang dikeluarkan.

\section{Manfaat kliring antara lain :}

1. Bagi masyarakat, memberikan alternatif pembayaran (transfer of valeu) efektif dan efisien dan aman.

2. Bagi bank, merupakan salah satu advantage service kepada nasabah, menjadi fee based income.

3. Bagi Bank sentral dapat secara cepat dan akurat mengetahui kondisi keuangan suatu bank maupun transaksi-transaksi yang terjadi di masyarakat.

tekhnis dan manajerial, serta aspek khusus. Sementara itu metode tidak langsung dilaksanakan selama Praktek Kerja Lapangan adalah mengumpulkan data sekunder dan studi pustaka.

baru diketahui setelah di berikan pada bank tersebut dan bank tersebut tidak langsung menolaknya.

5. Saat penyortiran warkat, tertinggal warkat riject yang seharusnya segera di tolak tetapi tertinggal jadi warkat tersebut harus segera di proses tolakan luar kliring

\section{Kendala yang dihadapi dan upaya untuk mencegahnya}

Selama melakukan Praktek Kerja Lapangan (PKL) terdapat beberapa kendala yang dihadapi:

1. Bila sistem komputer atau jaringan tidak stabil sehingga menyebabkan terjadi keterlambatan kerja. Upaya untuk mencegahnya, yaitu melakukan perawatan maintenance secara berkala 
setiap bulan dan perawatan dilakukan lebih intensif atau sering saat kondisi cuaca tidak mendukung yang dapat membuat jaringan menjadi tidak stabil seperti dua atau tiga kali dalam satu bulan pada komputer ataupun jaringan sehingga dapat meminimalisir ketidak stabilan tersebut.

2. DKE diterima penyelenggara sedangkan warkat tidak diterima penyelenggara (missing item). Upaya untuk

\section{Kesimpulan}

Berdasarkan Praktek Kerja Lapangan (PKL) yang telah dilakukan dan pembuatan karya ilmiah "Perlakuan Terhadap Warkat Yang Ditolak Pada Proses Kliring Pada Bank X (Persero)Tbk Area Bogor", dapat disimpulkan :

1. Proses kliring yang berlangsung pada PT Bank X (Persero) Tbk Area bogor juanda sudah berjalan dengan ketentuan yang telah diberikan oleh Bank Indonesia. Sehingga, tingkat kekeliruan maupun kesalahan dapat diminimalisasi.

Proses pelaksanaan kliring :

a. Nasabah $\mathrm{X}$ mengisi form aplikasi tranfer dana melalui kliring SKNBI ke nasabah Y melalui loket, internet banking atau saraana lainnya di bank A

b. Petugas bank A memebuat data keuangan (DKE) dan dikirimkan ke bank B melalui SKNBI

c. Bank indinesia sebagai penyelenggara SKNBI melakukan perhitungan dan mencegahnya, yaitu pihak pelaksana kliring harus mengecek data DKE (Data Keuangan Elektronik) agar sama dengan warkat yang diterima.

3. DKE tidak diterima penyelenggara sedangkan warkat diterima penyelenggara (unlisted item). Upaya untuk mencegahnya, yaitu pihak pelaksana kliring harus mengecek data DKE (Data Keuangan Elektronik) agar sama dengan warkat yang diterima.

meneruskan data keuangan elektronik dari bank A ke bank B setiap 2 jam sekali pada pukul 10.00 WIB, pukul 12.00 WIB, pukul 14.00 WIB dan pukul 16.00 WIB

d. Bank B membukukan tranfer dana dari nasabah $\mathrm{X}$ ke rekening nasabah $\mathrm{Y}$

e. Nasabah Y menerima dana dari nasabah X.

2. Alasan yang mengakibatkan terjadinya penolakan kliring yang sering terjadi di Bank X yaitu saldo rekening tidak cukup, tidak dicantumkannya tempat dan tanggal penarikan dan tidak terdapatnya tandatangan dan nama jelas.

3. Pelaksanaan kliring terdapat tolakan klring dimana tolakan kliring tersebut dapat mengganggu jalannya proses kliring dan pada tolakan kliring dibagi menjadi dua yaitu tolakan masuk dan tolakan kerluar dengan mengembalikan warkat tersebut melalui kliring return. 


\section{Daftar Pustaka}

Sumber Buku:

Irham Fahmi. 2014. Bank Dan Lembaga Keuangan Lainnya Teori Dan Aplikasi Bandung: Alfabeta

Kasmir , 2014. Bank Dan Lembaga Keuangan Lainnya. Jakarta : Penerbit PT RajaGrafindo Persada.

Kasmir, 2014. Dasar-dasar perbankan . Jakarta : penerbit PT RajaGrafindo Persada

Maryanto Supriyono, 2011. Buku Pintar Perbankan, Yogyakarta: Penerbit :CV Andi Offset
Julius R. Latumaerissa, 2011. Bank Dan Lembaga Keuangan Lannya. Jakarta : penerbit salemba empat Sumber Internet :

http://www.bankmandiri.co.id http://www.bi.go.id http://www.sumberpengertian.co/pengertianbank-sentral http://www.khanfarkan.com https://www.finansialmu.com/jenis-simpanantabungan-di-indonesia/ 